\title{
Localization of Muscarinic Receptors on Cultured Myenteric Neurons: A Combined Autoradiographic and Immunocytochemical Approach
}

\author{
Noel J. Buckley ${ }^{1}$ and Geoffrey Burnstock \\ Department of Anatomy and Embryology and Centre for Neuroscience, University College London, \\ London WC1E 6BT, England
}

\begin{abstract}
In order to localize the distribution of muscarinic receptors over the surface of cultured myenteric neurons, an autoradiographic procedure for detecting muscarinic receptors (using [ $\left.{ }^{3} \mathrm{H}\right]$ propylbenzilylcholine mustard; [ $\left.{ }^{3} \mathrm{H}\right] \operatorname{PrBCM}$ ) has been combined with an immunofluorescence procedure visualizing neuronal morphology (using an antibody raised against rat brain synaptosomes; anti-CTX). Using this technique, muscarinic receptors were localized over discrete areas of the neuronal cell surface. Receptors were seen to be widely distributed over the somata and neurites of $10-20 \%$ of cultured myenteric neurons. The greatest concentration of receptors occurred over the cell somata and proximal neurites. Receptors appeared evenly distributed over labeled cell somata, where their density was estimated to be between 30 and 100 receptors $/ \mu \mathrm{m}^{2}$. Distal regions of neurites were labeled intermittently with some varicosities and intervaricosities being labeled while others were unlabeled. Growth cones and nerve endings of labeled neurites were consistently labeled. The ability to localize muscarinic receptors on a subpopulation of immunocytochemically identified neurons enhances our understanding of muscarinic neurotransmission in myenteric neurons and provides an experimental system for the investigation of regulatory influences on neuronal neurotransmitter receptor expression and distribution.
\end{abstract}

The distribution of neurotransmitter receptors over the neuronal surface is fundamental to our understanding of neuronal function, yet few studies have addressed this question. Cell cultures provide useful systems for examining cellular distribution of receptors because of the ease with which the location of label over the surface of identified cells can be determined. Several previous studies have examined the distribution of $\alpha$-bungarotoxin binding sites in cultures of chick autonomic ganglia (Carbonetto and Fambrough, 1979; Gangitano et al., 1979; Greene et al., 1973; Messing and Gonatas, 1983; Messing and Kim, 1981; Ravdin and Berg, 1979). However, the lack of correlation between the toxin binding site and the nicotinic receptor mediating the physiological response (Brown and Fumagalli, 1977; Carbonetto et al., 1978; Kouvelas et al., 1978; Smith et al., 1983) undermines the usefulness of the neuronal toxin bind-

\footnotetext{
Received May 28, 1985; revised Aug. 20, 1985; accepted Aug. 21, 1985

This work was supported, in part, by the U.K. Medical Research Council and, in part, by a grant from Boehringer Ingelheim $\mathrm{GmBH}$. We would like to thank Dr. Andrew Matus (Friedrich-Miescher Institute, Basel, Switzerland) for providing the anti-CTX antiserum, and Ms. Doreen Bailey for preparing many of the cell cultures used in these studies.

Correspondence should be addressed to Professor Geoffrey Burnstock, Department of Anatomy and Embryology and Centre for Neuroscience, University College London, Gower Street, London WClE 6BT, U.K.

Present address: National Institute of Mental Health, Laboratory of Cell Biology, Bethesda, MD 20205.

Copyright (c) 1986 Society for Neuroscience $0270-6474 / 86 / 020531-10 \$ 02.00 / 0$
}

ing site as a model for studying neurotransmitter receptor expression and distribution.

In a preliminary study, we reported the use of the irreversible muscarinic antagonist, $\left[{ }^{3} \mathrm{H}\right]$ propylbenzilylcholine mustard $\left(\left[{ }^{3} \mathrm{H}\right] \operatorname{PrBCM}\right)$ to label muscarinic receptors on the surface of cultures of enteric ganglia (Buckley and Burnstock, 1984a). This compound provided a useful receptor label, since it had been demonstrated to be highly specific for the muscarinic receptor in several tissues (Burgen et al., 1974; Hulme et al., 1978; Ward and Young, 1977; Young et al., 1972) and had previously been used successfully in a series of autoradiographic studies to localize muscarinic receptors in brain slices (Kuhar et al., 1981; Rotter et al.,1979a-d). In addition, since only short incubation times ( $15 \mathrm{~min}$ ) in physiological buffers were used to label intact living cultures, the possibilities that either cytoplasmic sites were labeled or that labeled cell surface receptors were internalized were minimized. In this preliminary study, however, it was not possible to identify, unambiguously, labeled cell types or to localize the label over discrete areas of the cell surface. This was largely due to the limited morphological detail resolvable by bright-field microscopy. In order to overcome these constraints, we have developed a combined autoradiographic and immunofluorescence method for localizing muscarinic receptors over the surface of immunocytochemically identified neurons. In the present study, an antiserum raised against synaptic membranes from rat brain (anti-CTX; Matus et al., 1984) has been used to immunostain cultures of enteric ganglia that had previously been labeled with the muscarinic receptor ligand $\left[{ }^{3} \mathrm{H}\right] \operatorname{PrBCM}$. This antiserum has previously been shown to label specifically neuronal cell bodies and processes in cultures of several autonomic ganglia (M. J. Saffrey, N. J. Buckley, C. J. S. Hassall, A. Matus, and G. Burnstock, unpublished observations) and hence provides a useful tool for visualizing discrete areas of the neuronal cell surface. This study represents the first report of the localization of muscarinic receptors on immunocytochemically identified neurons.

\section{Materials and Methods}

\section{Cell culture}

Explants of myenteric plexus, free from connective tissue and smooth muscle, from the taenia coli of newborn guinea pig caeci were cultured as described by Jessen et al. (1983). Caeci with underlying circular muscle were dissected, cut into strips 2-4 mm long, and incubated in collagenase $(1 \mathrm{mg} / \mathrm{ml})$ overnight at $4^{\circ} \mathrm{C}$. This was followed by a further incubation for $2 \mathrm{hr}$ at $37^{\circ} \mathrm{C}$. The muscle layers could then be separated and the plexus dissected free. The plexuses were then allowed to adhere to glass coverslips and were assembled into modified Rose chambers. Growth medium consisted of medium 199 (Gibco) $+10 \%$ fetal calf serum $+0.5 \%$ glucose + antibiotics and was changed every week. Cultures were generally used between 7 and $14 \mathrm{~d}$, by which time many glia and fibroblasts had migrated from the explant and divided to produce an outgrowth region over which many varicose neurites traversed. 


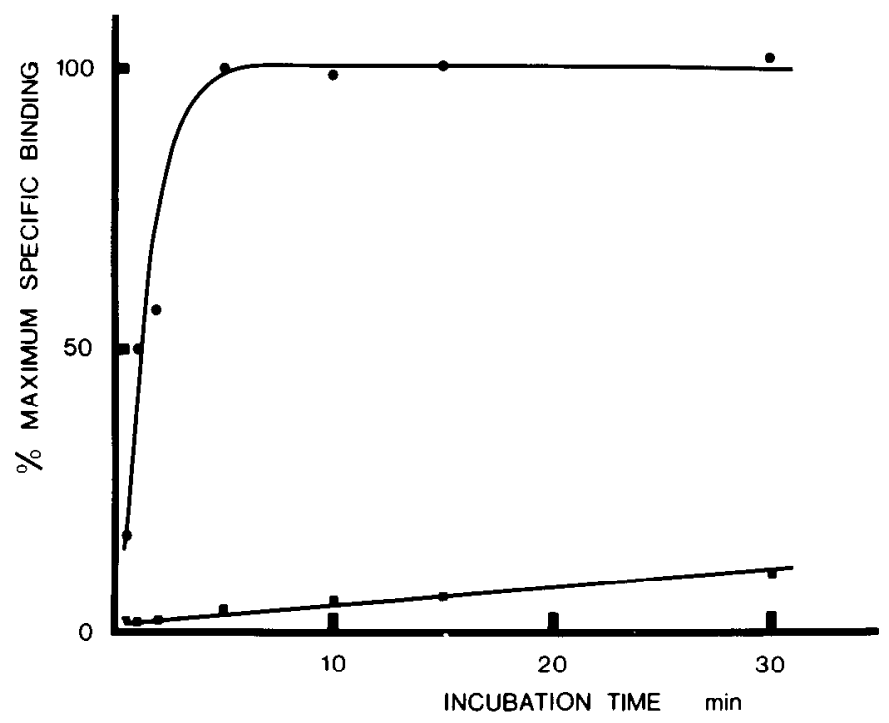

Figure 1. Specific and nonspecific binding of $\left[{ }^{3} \mathrm{H}\right] \operatorname{PrBCM}$ to myenteric explants as a function of time. Conditions of labeling were as described in Materials and Methods. Each point represents the mean of three independent experiments whose data varicd within $\pm 15 \%$.

\section{Labeling of cultures and myenteric explants with $\left.{ }^{3} \mathrm{H}\right] \operatorname{PrBCM}$}

Cultures and myenteric explants were labeled with $\left[{ }^{3} \mathrm{H}\right] \operatorname{PrBCM}$ by a modified version of Rotter et al. (1979a) as described previously (Buckley and Burnstock, 1984a). $\left[{ }^{3} \mathrm{H}\right] \mathrm{PrBCM}$ was first cyclized by diluting the commercial product (Amersham; $49 \mathrm{Ci} / \mathrm{mmol}$ ) to $1 \mu \mathrm{M}$ with $10 \mathrm{~mm}$ potassium phosphate buffer and allowing it to stand for $1 \mathrm{hr}$ at room temperature. Thereafter, the cyclized $\left[{ }^{3} \mathrm{H}\right] \mathrm{PrBCM}$ was kept on ice and used within $1 \mathrm{hr}$.

Explants of myenteric plexus from newborn guinea pig caeci were prepared as described above and preincubated for $15 \mathrm{~min}$ in Kreb's solution prior to incubation in Kreb's-containing $5 \mathrm{nM}$ [ $\left.{ }^{3} \mathrm{H}\right] \mathrm{PrBCM}$. All preincubations and incubations were carried out at $30^{\circ} \mathrm{C}$ with constant agitation. Control explants were preincubated and incubated in an identical manner except that $1 \mu \mathrm{M}$ atropine sulfate was included in the media. Following incubation, the explants were fixed in $4 \%$ paraformaldehyde in PBS for $30 \mathrm{~min}$ at room temperature, washed in several changes of $80 \%$ ethanol, rinsed in distilled water and then allowed to dry onto the surface of poly-L-lysine-coated microscope slides.

Cultures were treated similarly except that following the ethanol washes they were processed for immunocytochemistry (see below).

\section{Immunostaining of cultures with anti-CTX}

After washing in ethanol, labeled cultures were permeabilized with three 5 min washes in PBS $+0.1 \%$ Triton. An aliquot of rabbit anti-CTX (1:100 dilution) was then applied overnight at room temperature. The cultures were then washed $3 \times 5 \mathrm{~min}$ in PBS, followed by incubation in rhodamine-conjugated goat anti-rabbit immunoglobulin $\mathrm{G}$ (diluted $1: 100$ ) for $60 \mathrm{~min}$. Control cultures were incubated with an equivalent dilution of non-immune rabbit serum. All antisera were diluted in a buffer consisting of PBS $+0.1 \%$ Triton $+0.1 \%$ sodium azide $+0.01 \%$ BSA $+0.1 \%$ lysine. Preliminary studies had revealed that fluorescein conjugates were unsuitable for this procedure, since considerable fading of the fluorescent image occurred during the subsequent autoradiographic processing. The cultures were then washed again in PBS $(3 \times 5 \mathrm{~min})$, rinsed several times in distilled water and allowed to air-dry. At this point, it was possible to mount the cultures in PBS/glycerol (1:1) and to examine them with a fluorescent microscope in order to check the success of the immunohistochemical labeling. The dried cultures were then affixed to microscope slides with DPX mountant and processed for autoradiography (see below).

\section{Autoradiography}

Labeled explants and cultures were coated with nuclear emulsion (Ilford $\mathrm{K} 5$ diluted 1:1 with distilled water). After gelling and drying the emulsion, the slides were exposed in light-proof boxes at $4^{\circ} \mathrm{C}$ for $1-3$ months,

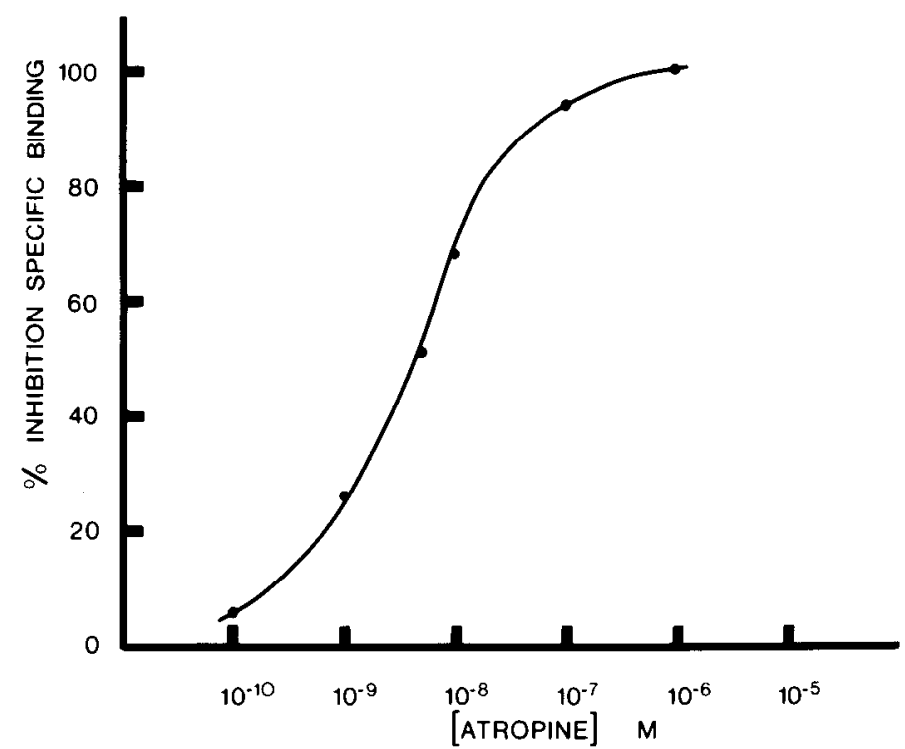

Figure 2. Displacement of specific $\left[{ }^{3} \mathrm{H}\right] \mathrm{PrBCM}$ binding to myenteric explants by atropine. Fifty percent inhibition occurs at $5 \times 10^{-9} \mathrm{M}$. Explants were labeled as described in Materials and Methods. Each point represents the mean of three independent experiments whose data varied within $\pm 15 \%$.

prior to development (undiluted Kodak D19;3 min at $18^{\circ} \mathrm{C}$ ) and fixation (Ilford Hypam $1: 4 ; 2$ min at $18^{\circ} \mathrm{C}$ ). The final autoradiograph was mounted in an antifade mountant (City University) and viewed with a Zeiss fluorescent microscope equipped with Nomarski interference optics. This arrangement allowed the examination of the autoradiograph silver grains and culture surface with transmitted light using Nomarski optics and concurrent visualization of the fluorescent image using a fluorescent epiluminescence optical system. For quantitative studies, autoradiograph grains were counted within a $20 \mu \mathrm{m}^{2}$ area using a Leitz photomicroscope.

\section{Results}

\section{Preliminary autoradiographic studies}

Preliminary quantitative autoradiographic studies were carried out to establish experimental conditions that ensured complete occupancy of all muscarinic receptors by $\left[{ }^{3} \mathrm{H}\right] \operatorname{PrBCM}$. Grain counts revealed that specific binding saturated after $5 \mathrm{~min}$, whereas nonspecific binding continued to rise slowly over a 30 min period (Fig. 1). Variation of the $\left[{ }^{3} \mathrm{H}\right] \mathrm{PrBCM}$ concentration between 2.5 and $10 \mathrm{~nm}$ did not significantly alter either specific or nonspecific binding (Table 1). Paraformaldehyde fixation, ethanolic washes, and incubation in aliquots of antibody overnight were also without effect on either specific or nonspecific binding (Table 2). Specific binding of [ $\left.{ }^{3} \mathrm{H}\right] \operatorname{PrBCM}$ was inhibited by atropine in a dose-dependent manner, with $50 \%$ inhibition occurring at $5 \times 10^{-9} \mathrm{M}$ (Fig. 2). Thus, incubation in $5 \mathrm{nM}$ [ $\left.{ }^{3} \mathrm{H}\right] \mathrm{PrBCM}$ for $15 \mathrm{~min}$ followed by fixation, washing, and application of anti-CTX overnight resulted in complete saturation of all muscarinic receptors.

\section{Anti-CTX immunoreactivity}

Immunocytochemistry revealed anti-CTX to stain all neurites along their entire length. The fluorescence intensity was variable, and while most processes were intensely stained, some neurites, especially some nonvaricose regions of neurites, appeared only moderately stained. Most varicosities fluoresced brightly; in addition, though, large intensely fluorescent varicosities could also be distinguished. These large varicosities were frequently, but not exclusively, situated in terminal regions of the neurites (Figs. 3 and 4). Neurites generally traversed fibroblasts in fascicules 


\section{Table 1. Specific and nonspecific binding of $\left[{ }^{3} \mathrm{H}\right] \operatorname{PrBCM}$}

\begin{tabular}{lll}
$\begin{array}{l}\text { Conc. cyclized } \\
\text { [ } \begin{array}{l}\text { [H]PrBCM } \\
\text { (nM) }\end{array}\end{array}$ & \multicolumn{2}{c}{ Autoradiograph grain densities } \\
\cline { 2 - 3 } & Specific & Nonspecific \\
\hline 2.5 & $102 \pm 8$ & $3 \pm(<1)$ \\
5.0 & $93 \pm 6$ & $3 \pm(<1)$ \\
10.0 & $97 \pm 6$ & $4 \pm(<1)$ \\
\hline
\end{tabular}

Explants were prepared and labeled as described in Materials and Methods. Nonspecific binding was assessed in the presence of $1 \mu \mathrm{M}$ atropine sulfate. Autoradiograph grains were counted over 30 areas of duplicate preparations. Results represent mean \pm SEM.

and occasionally nonfluorescent glial cells could be seen encapsulated within these bundles. Neurite bundles appeared nonvaricose, except in the vicinity of encapsulated glial cells, where varicosities could be distinguished (Fig. 3). Many neurites terminated as flattened swellings or growth cones with distinct filopodia (Figs. 3 and 4). Neuronal somata displayed intracellular staining with lightly fluorescent cytoplasm surrounding dark nuclei. A dim filamentous fluorescence was also observed in the perinuclear glial cell cytoplasm, while fibroblasts appeared to be unstained.

This pattern of labeling was identical in cultures that had previously been incubated in $\left[{ }^{3} \mathrm{H}\right] \mathrm{PrBCM}$ and was abolished by substituting non-immune normal rabbit serum for anti-CTX. Examination of the fluorescent image prior and subsequent to dipping in nuclear emulsion for autoradiography revealed a slight diminution in fluorescence intensity after exposure and development of the autoradiography. This was presumably due to fading of the immunofluorescence over the long exposure times employed (1-3 months).

\section{Combined autoradiography and immunocytochemistry}

Examination of autoradiographs prepared after incubation in anti-CTX revealed no differences in the pattern or density of labeling from that seen in cultures prepared for autoradiography only. The autoradiographs so obtained demonstrated the prescnce of silver grains over the cell bodies and processes of a subpopulation (10-20\%) of cultured myenteric neurons. Hence, the concurrent application of autoradiographic techniques to localize muscarinic receptors using $\left[{ }^{3} \mathrm{H}\right] \operatorname{PrBCM}$ and immunocytochemical procedures to visualize neuronal morphology with anti-CTX seems to be practicable and affords a greater degree of resolution for quantitation of receptor density.

Where individual cell bodies could be distinguished, those that were labeled gave rise to one or more labeled processes, while those cell bodies that were unlabeled did not appear to give rise to labeled fibers (Fig. 5). Cell bodies were labeled uniformly with no indication of clusters of autoradiograph grains.

Since little morphological detail could be resolved in the explant region, attention was focused on the distribution of silver grains over neurites in the outgrowth region, particularly on those areas where the neurite density was low enough to trace individual fibers unambiguously for several hundred microns. In a few instances, single labeled neurites could be followed for several thousand microns. This provided an opportunity to study the distribution of muscarinic receptors along considerable portions of the neurite. One such example is shown in Figure 6. In this case, the labeled cell body can also be seen. Preliminary estimates of receptor density on labeled cell bodies were carried out using the method described by Lane et al. (1977):

$$
R=\frac{g d \times A}{t S_{0} C}
$$

Table 2. Effects of histological processing on specific and nonspecific binding of $\left[{ }^{3} \mathrm{H}\right] \mathrm{PrBCM}$ to myenteric explants

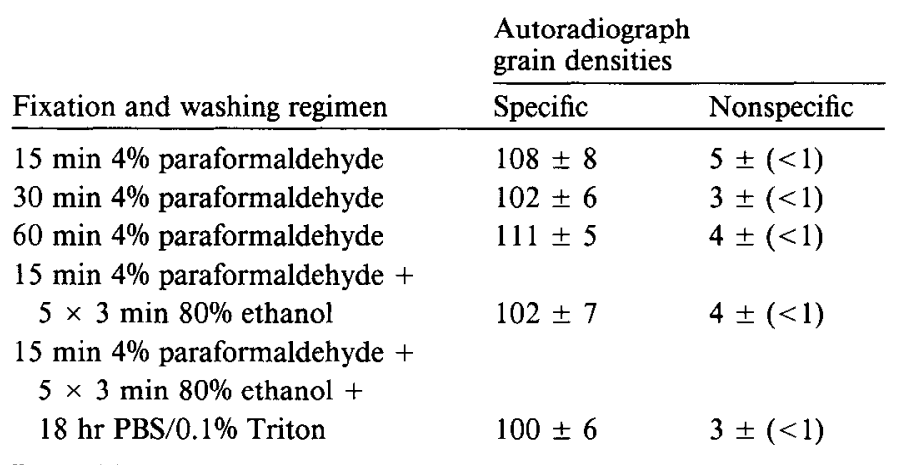

Explants were prepared and labeled as described in Materials and Methods. After labeling, the explants were subjected to various fixation and washing regimens before being dipped in nuclear emulsion and exposed for 3 weeks. Autoradiograph grain densities were then measured over 30 different areas of duplicate preparations. Nonspecific binding was assessed in the presence of $1 \mu \mathrm{M}$ atropine sulfate. Results represent mean \pm SEM.

where

$$
\begin{aligned}
R & =\text { no. rcceptors/unit arca } \\
g & =\text { no. grains/unit area } \\
d & =\text { no. decays/developed grain } \\
t & =\text { exposure time } \\
A & =\text { Avogadro's number } \\
S_{0} & =\text { specific activity of }\left[{ }^{3} \mathrm{H}\right] \mathrm{PrBCM} \\
C & =\text { decays } / \mathrm{Ci}
\end{aligned}
$$

Using this formula, a receptor density of between 30 and 100 receptors $/ \mu \mathrm{m}^{2}$ was estimated. Although the proximal regions of the neurite appear to be labeled fairly uniformly, as the fiber is traced progressively distally, the silver grains appear to be dispersed more discretely, with some regions of the neurite devoid of silver grains. This intermittent pattern of labeling was seen to be a consistent feature of most, if not all, labeled neurites. Grain counts performed over $100 \mu \mathrm{m}$ of neurite proximal to the cell body revealed a gradual decline in receptor number (Fig. 7). Unfortunately, the density of the neurite outgrowth surrounding the labeled cell bodies precluded any systematic tracing of neurites for more than $100 \mu \mathrm{m}$ from the cell body. However, grain counts over individual labeled neurites in the outgrowth region indicated a further decrease in receptor density per unit length of neurite.

Comparison of the fluorescent image with the autoradiograph image permitted the examination of receptor distribution over individual varicosities. Autoradiograph grains were present over both varicosities and intervaricose regions, but conversely, autoradiograph grains were completely absent from many varicosities and intervaricose regions (Fig. 4).

The growth cones of labeled neurites were consistently covered by autoradiograph grains. In some cases the labeled nerve endings appeared as flattened growth cones with distinct filopodia, whereas in other cases the neurite appeared to terminate as an amorphous swelling or flattened area (Figs. 3 and 4).

Neurite bundles were frequently seen traversing areas of fibroblasts. These fascicules were generally labeled uniformly along their length. Glial cells that were occasionally found encapsulated with neurite bundles were unlabeled, and no change in grain density was observed where the neurites became varicose in the vicinity of the glial cell.

\section{Discussion}

The present study represents the first report of the localization of a neurotransmitter receptor on the surface of immunocytochemically identified neurons. The application of concurrent 
Figure 3. Distribution of muscarinic receptors over neurite bundles and individual neurites in the outgrowth region of a culture of myenteric neurons. Fluorescent micrographs $A$ and $D$ show the appearance of the cultures immunostained with anti-CTX, while the micrographs $B, C$, and $E$ show the corresponding autoradiographs viewed with Nomarski optics. $A-C$, Distribution of autoradiograph grains along a neurite bundle containing a glial cell. Brightly fluorescent varicosities can be seen in the vicinity of the glial cell (arrowhead), but no corresponding change in grain density can be discerned in the autoradiographs (photographed at two focal planes). Examination of micrographs $D$ and $E$ shows autoradiograph grains distributed over the preterminal region and growth cone of a labeled neurite. Both varicosities $(v)$ and nonvaricose regions appear to be labeled. Scale bars, $10 \mu \mathrm{m}$.
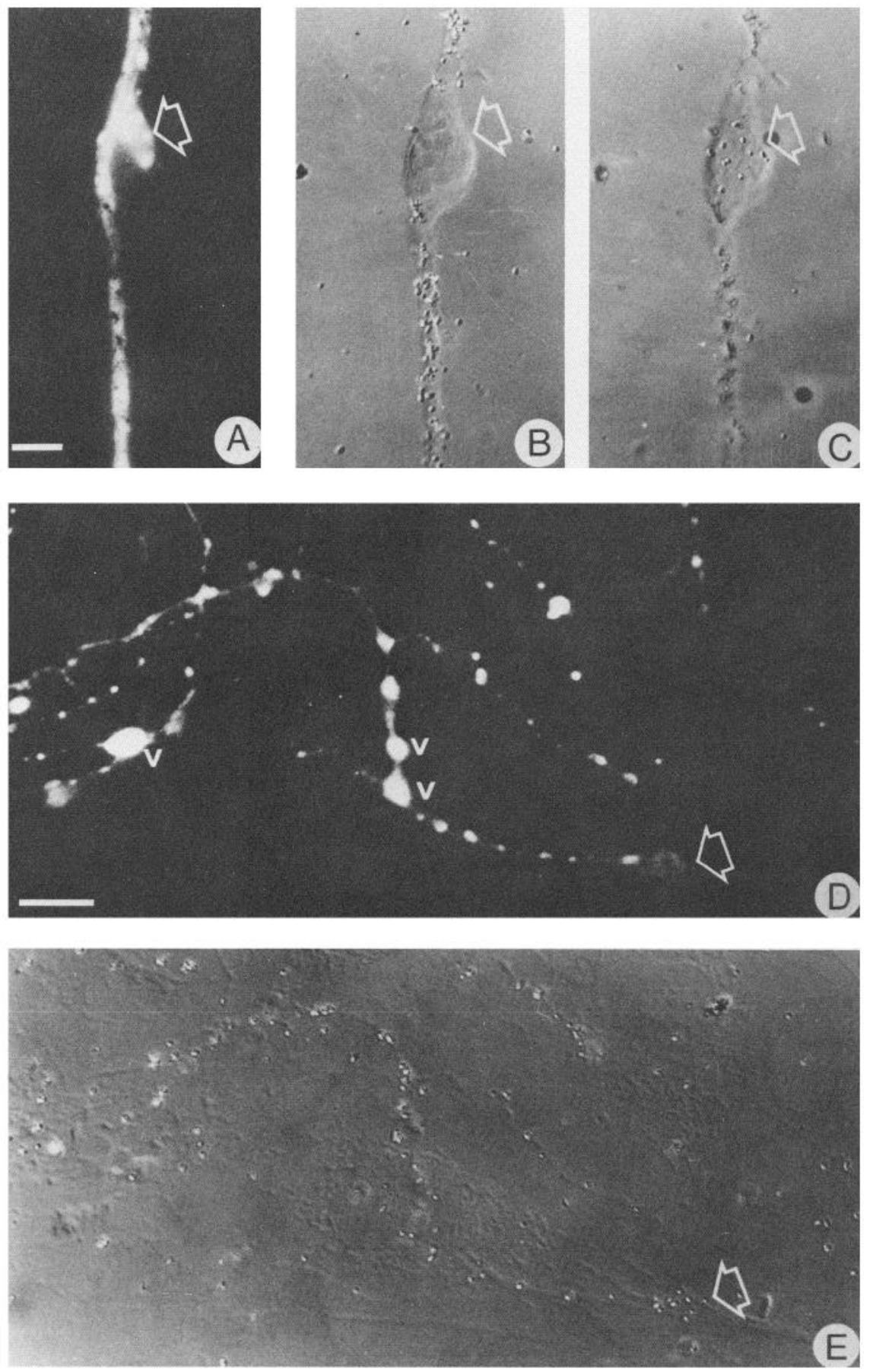

autoradiographic and immunocytochemical procedures clearly aids greatly in the visualization of muscarinic receptors over discrete areas of the neuronal cell surface.

Although it was not possible to trace any neuron completely, the observation that only those cell bodies that were labeled gave rise to labeled neurites supports the notion that approximately $10-20 \%$ of labeled myenteric neurons express muscarinic receptors over their cell somata and a large portion of their neurite membrane. In many cases, neuronal somata were covered with a dense neuropil, and this made it difficult to distinguish whether the overlying autoradiograph grains could be attributed to the neuronal cell surface or the neurites within the neuropil. In addition to the label seen over cell bodies, autoradiograph grains could be seen distributed along the neurites.
Receptor density appeared to be greatest over the neuronal somata and proximal regions of the neurites, while in the terminal and preterminal regions of the neurite, the density of receptors was lower and their distribution more intermittent. The estimated density of muscarinic receptors over the labeled cell somata $\left(30-100 / \mu \mathrm{m}^{2}\right)$ is similar to the density of $\alpha$-bungarotoxin binding sites on cultured chick sympathetic neurons (100-300/ $\mu \mathrm{m}^{2}$; Greene et al., 1973) but is much lower than either the density of muscarinic receptors on cultured cardiocytes (800/ $\mu \mathrm{m}^{2}$; Lane et al., 1977) or the density of nicotinic receptors at junctional sites $\left(9000 / \mu \mathrm{m}^{2}\right)$ or extrajunctional sites $\left(900 / \mu \mathrm{m}^{2}\right)$ on cultured chick myotubes (Sytkowski et al., 1973).

The presence of autoradiograph grains over growth cones indicates that insertion of muscarinic receptors into the neurite 

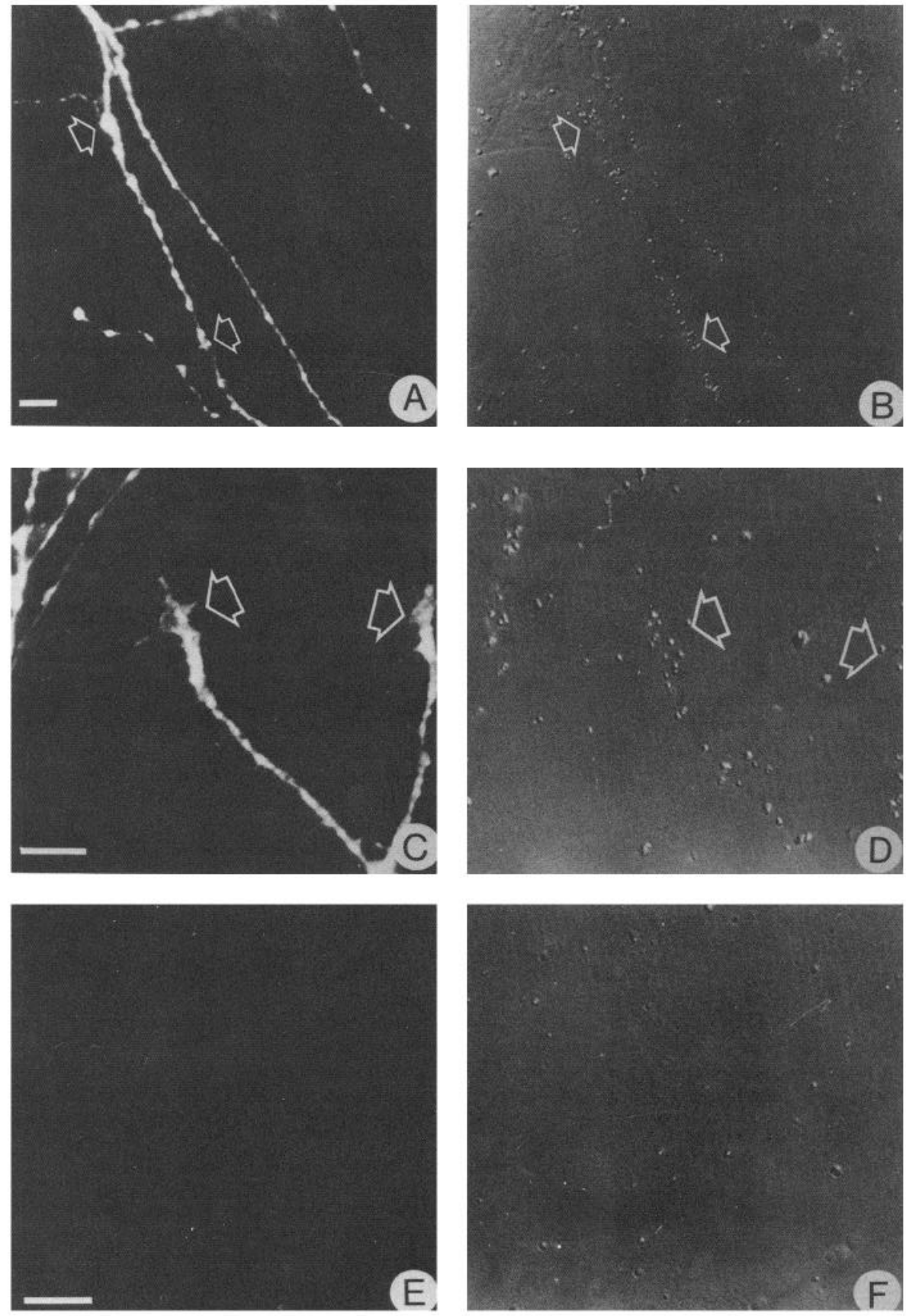

Figure 4. Distribution of muscarinic receptors over the surface of neurites in the outgrowth region of a culture of myenteric neurons. Fluorescent micrographs $A$ and $C$ show the appearance of cultures immunostained with anti-CTX, while autoradiographs $B$ and $D$ show the corresponding fields viewed with Nomarski interference optics. Comparison of $A$ with $B$ shows clusters of autoradiograph grains (arrowheads) overlying both varicose and nonvaricose regions of the neurites. $B$ and $D$ show the presence of autoradiograph grains over the growth cones (arrowheads) and preterminal regions of the neurites. $E$ and $F$ are fluorescence and interference micrographs of a culture incubated in non-immune rabbit serum (1:100 dilution) and atropine (1 $\mu \mathrm{M})$ to demonstrate nonspecific binding. Scale bars, $10 \mu \mathrm{m}$. membrane is an early event during neuronal development in culture, since the growth cone is believed to be the site of incorporation of newly synthesized membrane (Feldman et al., 1981; Pfenninger, 1979; Yamada et al., 1971). However, it is also possible that receptors are incorporated into the neurite membrane at sites other than the growth cone. The discontinuous distribution of receptors along the neurite could then be due to a heterogenous spatial distribution of such insertion or removal sites. Alternatively, such a distribution may be due to differing rates of receptor insertion and removal during extension of the neurite. Another possibility is that the heterogenous distribution arises because of redistribution of the receptors in the plane of the membrane subsequent to their incorporation.

The absence of any correlation between autoradiograph grain density and the presence of varicosities is most clearly illustrated in studies on neurite fascicules. Both ultrastructural and im- munocytochemical studies (Baluk et al., 1983; and N. J. Buckley, unpublished observations) have demonstrated that the neurites of these fascicules were varicose only in the vicinity of encapsulated glial cells. However, no difference was observed between the autoradiograph grain density overlying the varicose and nonvaricose regions. Although many of the large brightly fluorescent varicosities were labeled, it was not possible to discern unequivocally whether there was any selective accumulation of silver grains over these sites.

A number of studies have used neuronal cell cultures as models for studying receptor distribution on neuronal cell surfaces. Hösli and colleagues have attempted to overcome the problems of using reversible ligands as receptor labels by using cold or vapor aldehyde fixation followed by application of preformed layers of dry autoradiograph emulsion using a loop technique (Hösli and Hösli, 1982; Hösli et al., 1980). However, attempts to lo- 

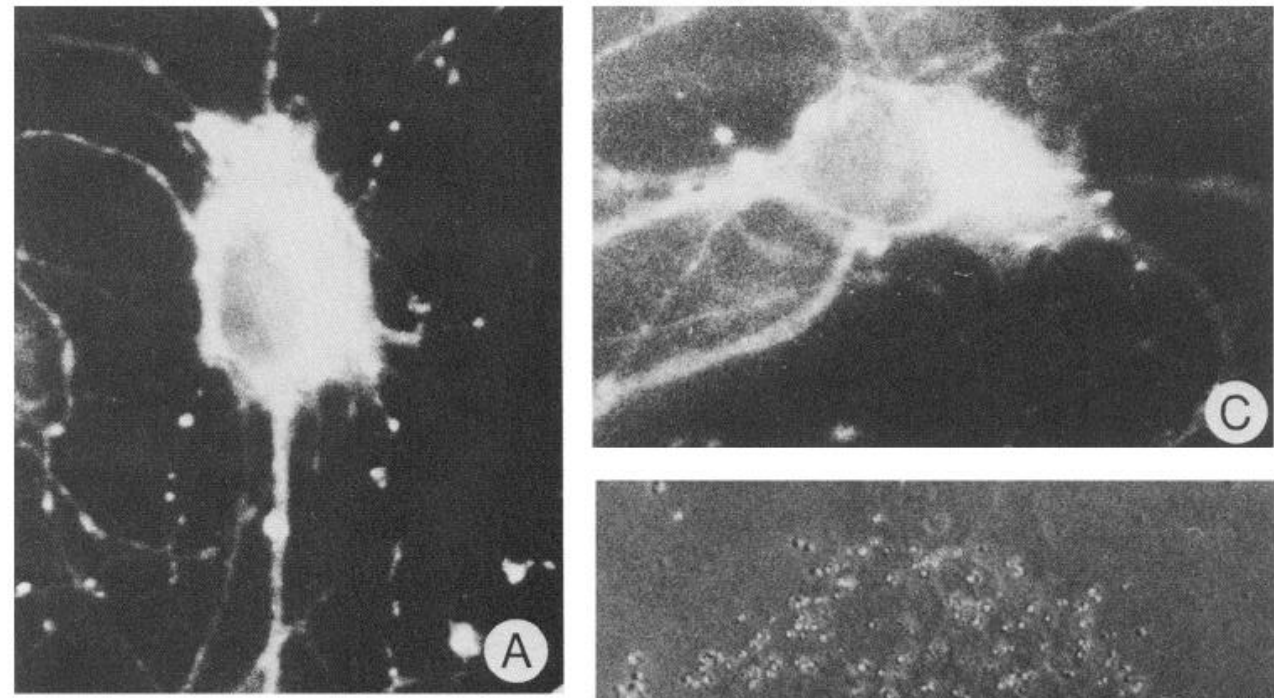

Figure 5. Labeled neuronal somata in cultures of myenteric ganglia. The fluorescence micrographs $A$ and $C$ show two neuronal cell bodies and neurites immunostained with antiCTX. Autoradiographs $B, D$, and $E$ show the corresponding fields viewed with Nomarski interference optics. In both cases, autoradiograph grains can be seen distributed over the cell surface and proximal neurites. Several unlabeled neurites can also be seen. $D, E$, Micrographs photographed at different focal planes in order to demonstrate the presence of autoradiograph grains over the entire surface of the cell body. Scale bars, $10 \mu \mathrm{m}$.
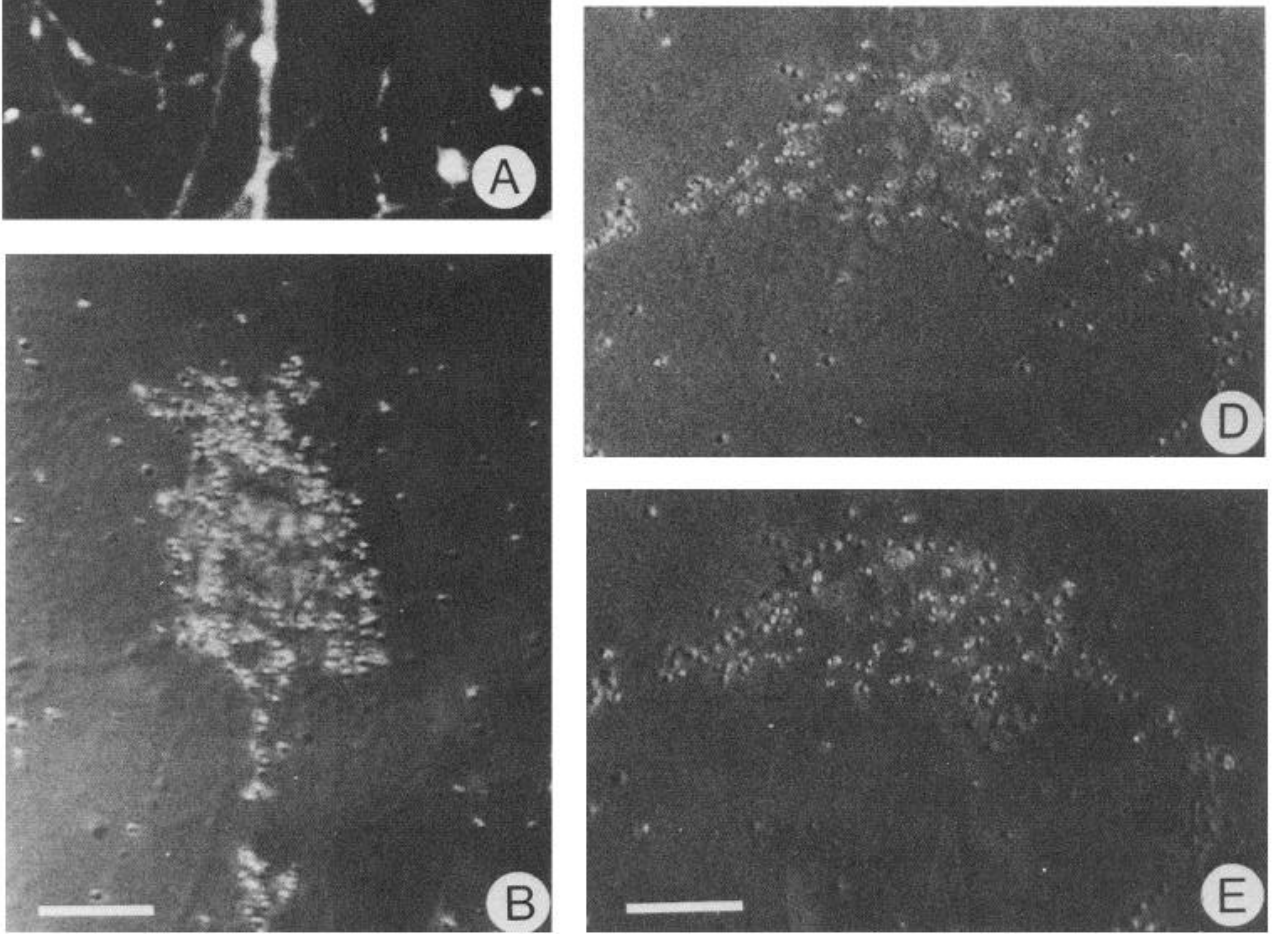

calize adrenergic and GABAerigic receptors on cultured neurons and glia from the CNS, using these procedures, have met with limited success, since many of the binding sites seem to be intracellular, as inferred from the absence of autoradiograph grains over cell nuclei. Irreversible ligands prove more suitable labels for receptor localization studies, since the ligand/receptor complex is stable to chemical fixation, thus improving preservation of cellular morphology and allowing the subsequent use of conventional dipping autoradiography and the consequent benefits of improved resolution.

The distribution of muscarinic receptors over the surface of cultured myenteric neurons resembled in many ways the distribution of $\alpha$-bungarotoxin binding sites over cultured chick autonomic neurons. A number of previous studies have used $\alpha$-bungarotoxin and cultures of chick autonomic ganglia as models for studying receptor distribution on neuronal cell surfaces (Carbonetto and Fambrough, 1979; Gangitano et al., 1979; Greene et al., 1973; Messing and Gonatas, 1983; Messing and Kim, 1981; Ravdin and Berg, 1979), although the usefulness of these models is limited by the absence of any clear, unequivocal correlation between the toxin binding site and the neuronal synaptic nicotinic receptor (Brown and Fumagalli, 1977; Carbonetto et al., 1978; Smith et al., 1983). As in the case of the muscarinic receptors in the present study, $\alpha$-bungarotoxin binding sites were distributed over the surface of both the soma and neurite. However, several differences were also apparent. First, muscarinic receptors were expressed by a discrete subpopulation of myenteric neurons, whereas all chick autonomic neurons possessed $\alpha$-bungarotoxin binding sites. Second, muscarinic receptors appeared to be distributed intermittently along the more distal regions of the neurites, whereas no such discontinuous distribution was reported in the case of $\alpha$-bungarotoxin binding sites. However, Carbonetto and Fambrough (1979), using dissociated chick sympathetic ganglia, also found a gradient of receptors away from the cell body toward the growth cone. Although $\alpha$-bungarotoxin receptors were seen over growth cones, these authors concluded that the growth cone could not be the principal site of receptor incorporation, since no difference was observed between the rates of receptor incorporation in isolated ganglia explants and isolated neurite outgrowth regions. This conclusion was supported by the observation that disruption of the growth cone with cytochalasin B had no effect on the rate of receptor incorporation.

The paucity of knowledge concerning receptor distribution on the neuronal surface in situ hinders any direct comparison with receptor distribution in cultured neurons. Such comparisons are largely founded on their expected distribution, based on physiological and pharmacological studies. Myenteric neurons are known to possess at least two types of muscarinic receptor: postsynaptic receptors, mediating a slow excitatory 

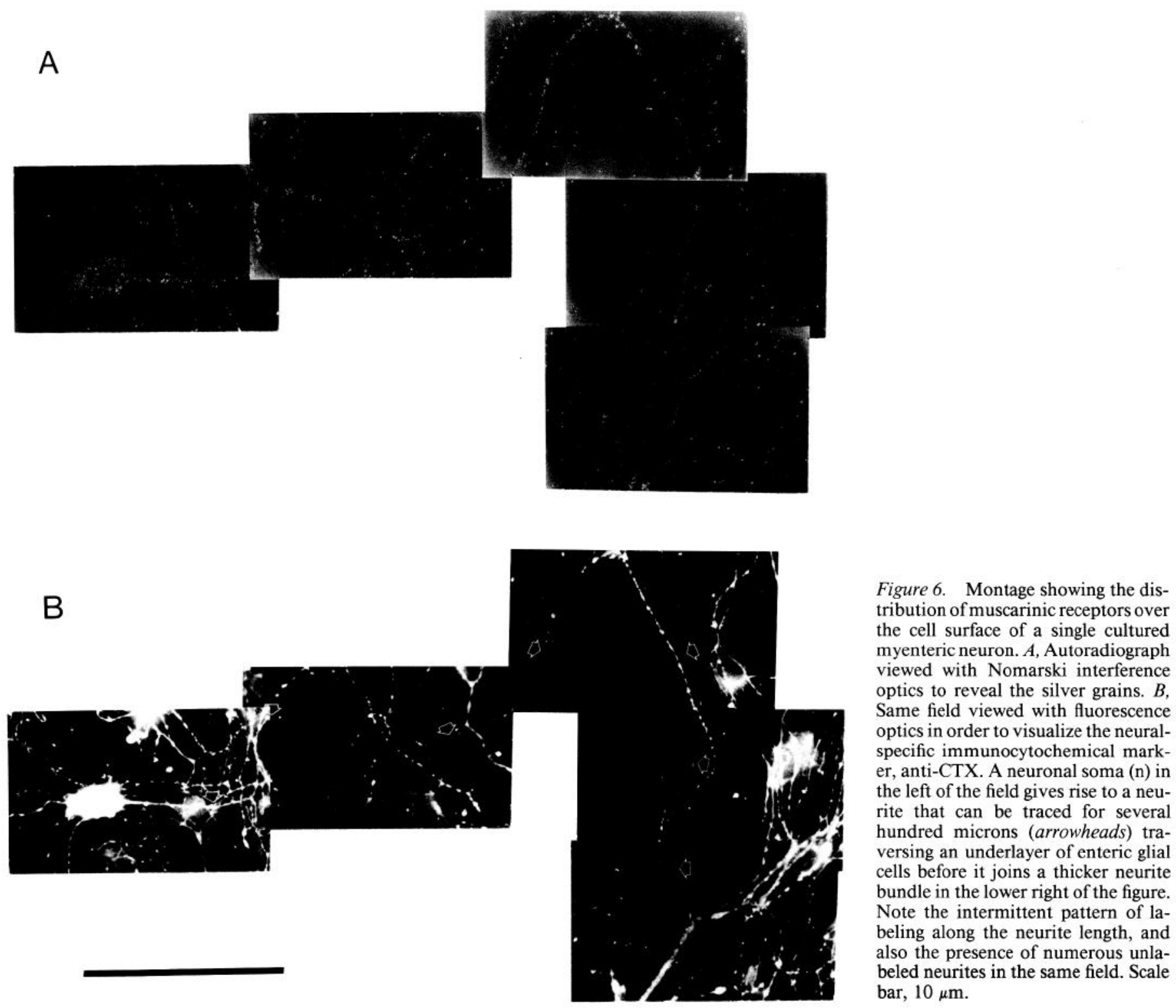

postsynaptic potential (North and Tokimasa, 1982), and prejunctional receptors, mediating inhibition of neurotransmitter release (Fosbraey and Johnson, 1980; Kilbinger, 1977; Kilbinger and Wagner, 1975; Kilbinger and Wessler, 1980; Morita et al., 1982). Although it has not been demonstrated whether myenteric neurons in culture continue to express these muscarinic functions, several other electrophysiological properties expressed by myenteric neurons in situ have been shown to be conserved in culture, including S- and AH-cell type behavior (Hanani et al., 1982; Jessen et al., 1978) and sensitivity to applied ACh (Hanani et al., 1982) and substance P (Hanani and Burnstock, 1984).

The fact that the fraction of cultured myenteric neuronal somata labeled by $\left[{ }^{3} \mathrm{H}\right] \operatorname{PrBCM}(10-20 \%)$ was similar to the proportion of myenteric neurons expressing a muscarinic slow epsp in situ (a quarter of S-type cells; North and Tokimasa, 1982) suggested that the labeled neurons corresponded to those neurons possessing postsynaptic muscarinic receptors (Buckley and Burnstock, 1984a). Previous autoradiographic studies have also demonstrated muscarinic receptors on enteric ganglia in situ (Buckley and Burnstock, 1984b, c), although it was not possible in this earlier study to identify labeled cell types or to determine whether the label was bound to cytoplasmic or cell surface sites.

The question then arises as to the possible function of the receptors present along the length of the neurites. One possibility is that these receptors may also be related to postsynaptic muscarinic responses. Previous studies have demonstrated that sensitivity to ACh (via nicotinic receptors) may not be restricted to the somatodendritic region of neurons. For example, in cultured leech neurons, depolarizations to applied acetylcholine can be detected along the length of the neurite and even over the growth cone (Pellegrino and Simonneau, 1984). Unmyelinated nerve fibers of the rabbit vagus have also been shown to be depolarized by applied ACh (Armett and Ritchie, 1961). Several biochemical studies have demonstrated the existence of muscarinic receptors (Laduron, 1980; Wamsley, 1983; Wamsley et al., 1981; Zarbin et al., 1982) along peripheral and central nerve trunks. However, since these studies involved labeling of cryostat sections, it is not possible to distinguish whether the label was bound to cytoplasmic or membrane-bound binding sites. Certainly, many of these receptors must be cytoplasmic, since they were seen to undergo axonal transport.

It is possible that muscarinic receptors along the neurites of cultured myenteric neurons may be involved in modulation of 
Figure 7. Autoradiograph grain density measured along the proximal $100 \mu \mathrm{m}$ of neurite. Grain density is expressed relative to the grain density overlying the most proximal $25 \mu \mathrm{m}$ section of neurite. The block to the right represents the grain density overlying more distal regions of the neurites. Numbers in parentheses represent the number of cells from which measurements were taken. Bars, SEM.

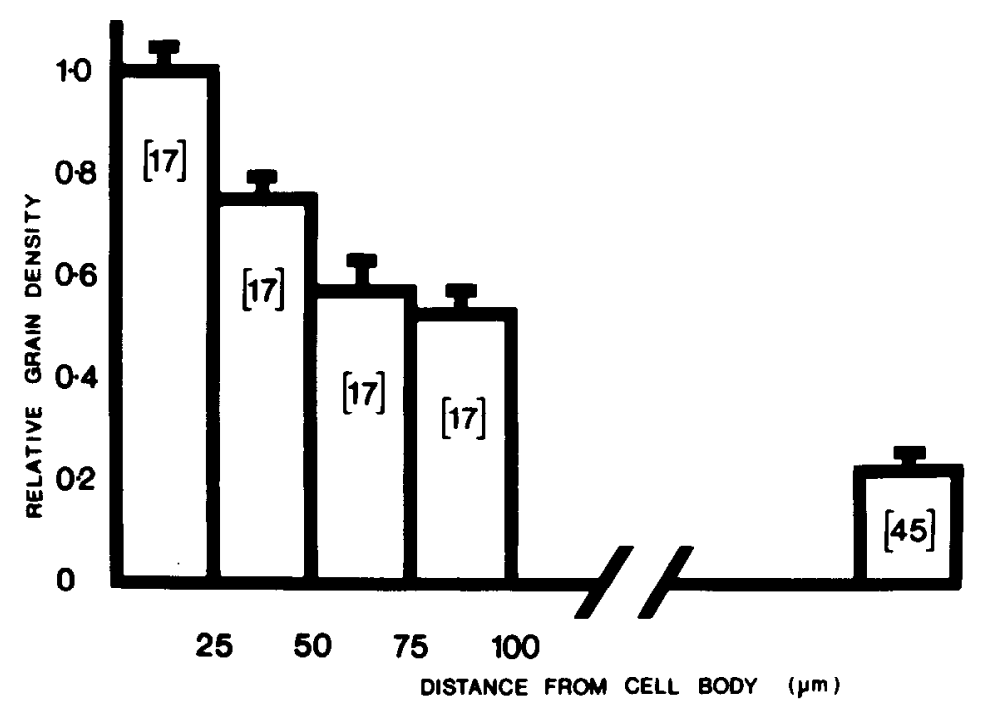

neurotransmitter release. Inhibition of neurotransmitter release from nerve terminals via prejunctional muscarinic receptors has been demonstrated in scveral peripheral nerves (see Vizi, 1979; Westfall, 1977) including the myenteric plexus of guinea pig ileum (Fosbraey and Johnson, 1980; Kilbinger, 1977; Kilbinger and Wagner, 1975; Kilbinger and Wessler, 1980; Morita et al., 1982). Current concepts of prejunctional modulation of neurotransmitter release encompass two fundamentally different mechanisms. On the one hand, neurotransmitter release may be modulated by receptors that modulate the amount of neurotransmitter released from nerve varicosities (i.e., via control of electrosecretory coupling) or, on the other hand, release may be modulated by receptors that control the number of varicosities involved in the release of neurotransmitter (i.e., via control of varicosity recruitment). The former mechanism is hypothesized to occur via modulation of $\mathrm{Ca}^{2+}$ influx (see Vizi, 1979; Westfall, 1977) or alterations in the activity of $\mathrm{Na}^{+} / \mathrm{K}^{+}$adenosine triphosphatase (see Vizi, 1979). The latter mechanism is believed to operate via control of impulse spread into the terminal varicosities (see Stjärne, 1978). The first model implies an association between prejunctional receptors and the sites of release (i.e., varicosities), whereas the second model does not necessitate such an association. The majority of muscarinic receptors on the neurites of cultured myenteric neurons do not appear to be associated with varicosities, so correspondingly few could be concerned with control of electrosecretory coupling. Although varicosities observed in situ appear to be static (see McMahan and Kuffler, 1971), many varicosities in cultured neurons appear to flow along the neurites (G. Greenberg and G. Burnstock, unpublished observations), indicating perhaps a more transient relation between varicosities and receptors on the neurite surface in cultured neurons. It is also conceivable that receptors may be incorporated randomly into the neuronal membrane. It may only be subsequent to their initial incorporation that receptors may be redistributed on the cell surface. This may be especially pertinent to cultured neurons, since many of the cellular influences that might be expected to determine receptor distribution have been disrupted. Such factors could include a normal prejunctional input. Both denervated skeletal muscle (Miledi, 1960) and denervated nerve cells (Kuffler et al., 1971; Roper, 1976) show an increase in extrajunctional sensitivity to applied ACh, and in the case of muscle, these changes have been seen to be accompanied by a decrease in the density of junctional receptors and an increase in the density of extrajunctional receptors (Fambrough, 1974; Hartzell and Fambrough, 1972; Miledi and Potter, 1971). Exlracts of nervous tissue (Jessell et al., 1979; Kalcheim et al., 1982; Podleski et al.,
1978), conditioned medium from neuronal cell cultures (Christian et al., 1978; Schaffner and Daniels, 1982), and basal lamina components (Nitkin ct al., 1983; Vogel ct al., 1983) have all been shown to be capable of influencing the aggregation of nicotinic cholinergic receptors on cultured myotubes, yet nothing is known of their possible effects on the expression and distribution of neuronal receptors.

In conclusion, the combination of autoradiography, immunocytochemistry and tissue culture allows a detailed analysis of the distribution of muscarinic receptors on the surface of identified cell types. Although it is possible that the localization of muscarinic receptors over the somata and neurites of myenteric neurons may be related to postsynaptic and prejunctional muscarinic actions expressed in situ, it is also possible that the distribution of receptors on cultured neurons differs from their distribution in situ. Nevertheless, the experimental system described here may provide a useful model for determining regulatory influences that determine the expression and distribution of neuronal neurotransmitter receptors. In addition, we are currently using this combined autoradiographic and immunocytochemical procedure to identify chemically those cells expressing muscarinic receptors by using a range of antisera directed against endogenous neuroactive substances.

\section{References}

Armett, C. J., and J. M. Ritchie (1961) The action of acetylcholine and some related substances on conduction in mammalian non-myelinated fibres. J. Physiol. (Lond.) 155: 372-384.

Baluk, P., K. R. Jessen, M. J. Saffrey, and G. Burnstock (1983) The enteric nervous system in tissue culture. II. Ultrastructural studies of cell types and their relationships. Brain Res. 262: 37-47.

Brown, D. A., and L. Fumagalli (1977) Dissociation of $\alpha$-bungarotoxin binding and receptor block in the rat superior cervical ganglion. Brain Res. 129: 165-168.

Buckley, N. J., and G. Burnstock (1984a) The distribution of muscarinic receptors on cultured myenteric neurons. Brain Res. 310: 133137.

Buckley, N. J., and G. Burnstock (1984b) Autoradiographic localisation of peripheral muscarinic receptors. In Subtypes of Muscarinic Receptors, B. I. Hirschowitz, R. Hammer, A. Giachetti, J. J. Keirns, and R. R. Leowi, eds., (1984) Trends Pharmacol. Sci. (Suppl.): 5559.

Buckley, N. J., and G. Burnstock (1984c) Autoradiographic localisation of muscarinic receptors in guinea-pig intestine: Distribution of high and low affinity agonist binding sites. Brain Res. 294: 15-22.

Burgen, A. S. V., C. R. Hiley, and J. M. Young (1974) The binding of $\left[{ }^{3} \mathrm{H}\right]$ propylbenzilylcholine mustard by longitudinal muscle strips from guinea-pig small intestine. Br. J. Pharmacol. 50: 145-151. 
Carbonetto, S., and D. M. Fambrough (1979) Synthesis, insertion into the plasma membrane and turnover of $\alpha$-bungarotoxin receptors in chick sympathetic ganglion. J. Cell Biol. 81: 555-569.

Carbonetto, S. T., D. M. Fambrough, and K. J. Muller (1978) Nonequivalence of $\alpha$-bungarotoxin receptors and acetylcholine receptors in chick sympathetic neurons. Proc. Natl. Acad. Sci. USA 75: 10161020.

Christian, C. N., M. P. Daniels, H. Sugiyama, Z. Vogel, L. Jacques, and P. G. Nelson (1978) A factor from neurons increases the number of acetylcholine receptor aggregates on cultured muscle cells. Proc. Natl. Acad. Sci. USA 75: 4011-4015.

Fambrough, D. M. (1974) Acetylcholine receptors: Revised estimates of extrajunctional receptor density in denervated rat diaphragm. J. Gen. Physiol. 64: 468-472.

Feldman, E. L., D. Axelrod, M. Schwartz, A. M. Heacock, and B. W. Agranoff (1981) Studies on the localization of newly added membrane in growing neurites. J. Neurobiol. 12: 591-598.

Fosbraey, P., and E. S. Johnson (1980) Release-modulating acetylcholine receptors on cholinergic neurones of the guinea-pig ileum. Br. J. Pharmacol. 68: 289-300.

Gangitano, C., L. Fumagalli, and N. Miani (1979) Appearance of new $\alpha$-bungarotoxin-acetylcholine receptors in cultured sympathetic ganglia of chick embryos. Brain Res. 161: 131-141.

Greene, L. A., A. J. Sytkowski, Z. Vogel, and M. W. Nirenberg (1973) $\alpha$-Bungarotoxin used as a probe for acetylcholine receptors of cultured neurons. Nature 243: 163-166.

Hanani, M., and G. Burnstock (1984) Substance P evokes slow and fast responses in cultured myenteric neurons of the guinea-pig. Neurosci. Lett. 48: 19-23.

Hanani, M., P. Baluk, and G. Burnstock (1982) Myenteric neurons express electrophysiological and morphological diversity in tissue culture. J. Auton. Nerv. Syst. 5: 155-164.

Hartzell, H. C., and D. M. Fambrough (1972) Acetylcholine receptors. Distribution and extrajunctional density in rat diaphragm after denervation correlated with acetylcholine sensitivity. J. Gen. Physiol. 60: 248-262.

Hösli, E., and L. Hösli (1982) Evidence for the existence of $\alpha$ - and $\beta$-adrenoceptors on neurons and glial cells of cultured rat central nervous system - an autoradiographic study. Neuroscience 7:28732881.

Hösli, E., H. Möhler, J. C. Richards, and L. Hösli (1980) Autoradiographic localization of binding sites for $\left[{ }^{3} \mathrm{H}\right]$ aminobutyrate, $\left[{ }^{3} \mathrm{H}\right]$ muscimol, $(+)\left[{ }^{3} \mathrm{H}\right]$ bicuculline methiodiole and $\left[{ }^{3} \mathrm{H}\right]$ fluritrazepam in culture of rat cerebellum and spinal cord. Neuroscience $5: 1657-$ 1665 .

Hulme, E. C., N. J. M. Birdsall, A. S. V. Burgen, and P. Menta (1978) The binding of antagonists to brain muscarinic receptors. Mol. Pharmacol. 14: 737-750.

Jessell, T. M., R. E. Siegel, and G. D. Fishbach (1979) Induction of acetylcholine receptors on cultured skeletal muscle by a factor extracted from brain and spinal cord. Proc. Natl. Acad. Sci. USA 76 . 5397-5401.

Jessen, K. R., J. D. McConnell, R. D. Purves, G. Burnstock, and J. Chamley-Campbell (1978) Tissue culture of mammalian enteric neurons. Brain Res. 152: 573-579.

Jessen, K. R., M. J. Saffrey, and G. Burnstock (1983) The enteric nervous system in tissue culture. I. Cell types and their interactions in explants of the myenteric and submucous plexuses from guineapig, rabbit and rat. Brain Res. 262: 17-35.

Kalcheim, C., Z. Vogel, and D. Duskin (1982) Embryonic brain extract induces collagen biosynthesis in cultured muscle cells: Involvement in acetylcholine receptor aggregation. Proc. Natl. Acad. Sci. USA 79: 3077-3081.

Kilbinger, H. (1977) Modulation by oxotremorine and atropine of acetylcholine release evoked by electrical stimulation of the myenteric plexus of guinea-pig ileum. Naunyn Schmiedebergs Arch. Pharmacol. 300: 145-151.

Kilbinger, H., and P. Wagner (1975) Inhibition by oxotremorine of acetylcholine resting release from guinea-pig ileum longitudinal muscle strips. Naunyn Schmiedebergs Arch. Pharmacol. 287: 47-60.

Kilbinger, H., and I. Wessler (1980) Inhibition by acetylcholine of the stimulation-evoked release of ${ }^{3} \mathrm{H}$-acetylcholine from the guinea-pig myenteric plexus. Neuroscience 5: 1331-1340.

Kouvelas, E. D., M. A. Dichter, and L. A. Greene (1978) Chick sympathetic neurons develop receptors for $\alpha$-bungarotoxin in vitro, but the toxin does not block nicotinic receptors. Brain Res. 158: 83-93.
Kuffler, S. W., M. J. Dennis, and A. J. Harris (1971) The development of chemosensitivity in extrasynaptic areas of the neuronal surface after denervation of parasympathetic ganglion cells in the heart of the frog. Proc. R. Soc. Lond. [Biol.] 177: 555-563.

Kuhar, M. I., N. Taylor, J. K. Wamsley, E. C. Hulme, and N. J. M. Birdsall (1981) Muscarinic cholinergic receptor localization in brain by electron microscopic autoradiography. Brain Res. 216: 1-9.

Laduron, P. (1980) Axoplasmic transport of muscarinic receptors Nature 286: 287-288.

Lane, M. A., A. Sastre, M. Law, and M. M. Salpeter (1977) Cholinergic and adrenergic receptors on mouse cardiocytes in vitro. Dev. Biol. 57: 254-269.

McMahan, U. J., and S. W. Kuffler (1971) Visual identification of synaptic boutons on living ganglion cells and of varicosities in postganglionic axons in the heart of the frog. Proc. R. Soc. Lond. [Biol.] 177: 485-508.

Matus, A., M. Ng, G. Pehling, M. Ackermann, and K. Hauser (1984) Surface antigens of brain synapses: identification of minor proteins using polyclonal antisera. J. Cell Biol. 98: 237-245.

Messing, A., and N. K. Gonatas (1983) Extra-synaptic localization of $\alpha$-bungarotoxin receptors in cultured chick ciliary ganglion cells. Brain Res. 269: 172-176.

Messing, A., and S. U. Kim (1981) Development of $\alpha$-bungarotoxin receptors in cultured chick ciliary ganglion neurons. Brain Res. 208. 479-486.

Miledi, R. (1960) The acetylcholine sensitivity of frog muscle fibres after complete or partial denervation. J. Physiol. (Lond.) 151: 1-23.

Miledi, R., and L. T. Potter (1971) Acetylcholine receptors in muscle fibres. Nature 233: 599-603.

Morita, K., R. A. North, and T. Tokimasa (1982) Muscarinic presynaptic inhibition of synaptic transmission in myenteric plexus of guinea-pig ileum. J. Physiol. (Lond.) 333: 141-149.

Nitkin, R. M., B. G. Wallace, M. E. Spira, E. W. Godfrey, and U. J. McMahan (1983) Molecular components of the synaptic basal lamina that direct differentiation of regenerating neuromuscular junction. Cold Spring Harbor Symp. Quant. Biol. 48: 653-665.

North, R. A., and T. Tokimasa (1982) Muscarinic synaptic potentials in guinea-pig myenteric plexus neurones. J. Physiol. (Lond.) 333: 151156.

Pellegrino, M., and M. Simonneau (1984) Distribution of receptors for acetylcholine and 5-hydroxytryptamine on identified leech neurones growing in culture. J. Physiol. (Lond.) 352: 669-684.

Pfenninger, K. H. (1979) Synaptic-membrane differentiation. In Neurosciences 4th Study Program, F. O. Schmitt and F. G. Worden, eds. pp. 779-795, MIT Press, Cambridge, MA.

Podleski, T. R., D. Axelrod, P. Ravdin, I. Greenberg, M. M. Johnson, and M. M. Salpeter (1978) Nerve extract induces increase and redistribution of acetylcholine receptors on clonal muscle cells. Proc Natl. Acad. Sci. USA 75: 2035-2039.

Ravdin, P. M., and D. K. Berg (1979) Inhibition of neuronal acetylcholine sensitivity by $\alpha$-toxin from Bungarus multicinctus venom Proc. Natl. Acad. Sci. USA 76: 2072-2076.

Roper, S. (1976) The acetylcholine sensitivity of the surface membrane of multiply-innervated parasympathetic ganglion cells in the mud puppy before and after partial denervation. J. Physiol. (Lond.) 254 : $455-473$.

Rotter, A., N. J. M. Birdsall, A. S. V. Burgen, P. M. Field, E. C. Hulme, and G. Raisman (1979a) Muscarinic receptors in the central nervous system of the rat. I. Technique for autoradiographic localization of the binding of $\left[{ }^{3} \mathrm{H}\right]$ propylbenzilylcholine mustard and its distribution in the forebrain. Brain Res. Rev. 1: 141-165.

Rotter, A., N. J. M. Birdsall, P. M. Field, and G. Raisman (1979b) Muscarinic receptors in the central nervous system of the rat. II. Distribution of binding of $\left[{ }^{3} \mathrm{H}\right]$ propylbenzilylcholine mustard in the midbrain and hindbrain. Brain Res. Rev. 1: 167-183.

Rotter, A., P. M. Field, and G. Raisman (1979c) Muscarinic receptors in the central nervous system of the rat. II. Postnatal development of binding of $\left[{ }^{3} \mathrm{H}\right]$ propylbenzilylcholine mustard. Brain Res. Rev. 1: 185-205.

Rotter, A., N. J. M. Birdsall, A. S. V. Burgen, P. M. Field, A. Smolen, and G. Raisman (1979d) Muscarinic receptors in the central nervous system of the rat. IV. A comparison of the effects of axotomy and deafferentation on the binding of $\left[{ }^{3} \mathrm{H}\right]$ propylbenzilylcholine mustard and associated synaptic changes in the hypoglossal and pontine nuclei. Brain Res. Rev. 1: 207-224.

Schaffner, A. E., and M. P. Daniels (1982) Conditioned medium from 
cultures of embryonic neurons contains a high molecular weight factor which induces acetylcholine receptor aggregation on cultured myotubes. J. Neurosci. 2: 623-632.

Smith, M. A., J. F. Margiotta, and D. K. Berg (1983) Differential regulation of acetylcholine sensitivity and $\alpha$-bungarotoxin binding sites on ciliary ganglion neurons in cell culture. J. Neurosci. 3: 23952402.

Stjärne, L (1978) Inhibitory effects of noradrenaline and prostaglandin E2 on neurotransmitter secretion evoked by single shocks or by short trains of nerve stimuli. Acta Physiol. Scand. 102: 251-253.

Sytkowski, A. J., Z. Vogel, and M. W. Nirenberg (1973) Development of acetylcholine receptor cluster on cultured muscle cells. Proc. Natl. Acad. Sci. USA 70: 270-274.

Vizi, E. S. (1979) Presynaptic modulation of neurochemical transmission. Prog. Neurobiol. 12: 181-290.

Vogel, Z., C. N. Christian, M. Vigny, H. C. Bauer, P. Sonderegger, and M. P. Daniels (1983) Laminin induces acetylcholine receptor aggregation on cultured myotubes and enhances the receptor aggregation activity of a neuronal factor. J. Neurosci. 3: 1058-1068.
Wamsley, J. K. (1983) Muscarinic cholinergic receptors undergo axonal transport in the brain. Eur. J. Pharmacol. 86: 309-310.

Wamsley, J. K., M. A. Zarbin, and M. J. Kuhar (1981) Muscarinic cholinergic receptors flow in the sciatic nerve. Brain Res. 217: 155161.

Ward, D., and J. M. Young (1977) Ligand binding to muscarinic receptors in intact longitudinal muscle strips from guinea-pig intestine. Br. J. Pharmacol. 61: 189-197.

Westfall, T. C. (1977) Local regulation of adrenergic neurotransmission. Physiol. Rev. 57: 659-728.

Yamada, K. M., B. S. Spooner, and N. K. Wessells (1971) Ultrastructure and function of growth cones and axons of cultured nerve cells. J. Cell Biol. 49: 614-635.

Young, J. M., R. Hiley, and A. S. V. Burgen (1972) Homologues of benzilylcholine mustard. J. Pharm. Pharmacol. 24: 950-954.

Zarbin, M. A., J. K. Wamsley, and M. J. Kuhar (1982) Axonal transport of muscarinic cholinergic receptors in rat vagus nerve: high and low affinity agonist receptors move in opposite directions and differ in nucleotide sensitivity. J. Neurosci. 2: 934-941. 